A warning by the glaciologist is hardly taken seriously unless it includes a forecast of the time of final rupture. At present the most promising approach for such a prediction is the almost perfect regularity by which certain large ice masses accelerate for a very long time prior to the instant when the avalanche starts to fall (see the Weisshorn case). The limitation of the forecasts lies as much in short-term irregularities as in the extreme difficulties of obtaining sufficiently accurate data without interruptions, and further in the lack of experience on the critical velocity that is reached immediately before final breakage. The physical explanation of the observed law is another question. Using a finite-element computational model for the analysis of stress and flow in a somewhat different case, Iken (1977) has shown that a stepwise crack extension alternating with phases of flow leads to the observed form of velocity-time relationship.

There are various possibilities in the way of preventive measures; none of them is completely satisfactory, however. The most certain consists in avoiding the danger zone altogether, a solution usually not acceptable to those involved. In view of the requirements necessary for withstanding an impact of exceptional magnitude, protective structures are generally not practical either. A stepwise elimination of the unstable ice mass by blasting could be considered, though the realization would be difficult and not without danger - not to speak of the legal problem encountered if the blasting should trigger the full-size avalanche. Consequently a certain calculated risk will occasionally have to be accepted whereby the dangers during an operation on the glacier and the extreme costs have to be weighed against the severity and small probability of a catastrophe. Viewed in proportion to other risks in everyday life (especially in road and air traffic, but also in relation to earthquakes), the dangers of ice avalanches should not be exaggerated.

Glaciological research can obviously contribute in a variety of ways to the solution of practical problems with ice avalanches, and there are ample opportunities for future studies. Of urgent need are more and better observations on almost every aspect of the problem, extending to phenomena hitherto not observed such as frequency and intensity of seismic signals. The inherent difficulty with the more interesting large-scale events is their scarcity, precluding proper experimentation. Advances in the theoretical treatment are also to be hoped for. There is also room for new ideas, for instance on how to prevent a particular ice mass from forming.

\title{
REFERENCES
}

Heim, A. 1896. Die Gletscherlawine an der Altels am I I. September I 895. $98^{\text {stes }}$ Neujahrsblatt der Naturforschenden Gesellschaft in Zürich, $1895,63 \mathrm{p}$.

Iken, A. I977. Movement of a large ice mass before breaking off. Journal of Glaciology, Vol. I 9, No. 8I, p. 595-6o5.

Morales, B. 1966. The Huascarán avalanche in the Santa valley, Peru. Union de Géodésie et Géophysique Internationale. Association Internationale d'Hydrologie Scientifique. Commission pour la Neige et la Glace. Division Neige Saisonnière et Avalanches. Symposium international sur les aspects scientifiques des avalanches de neige, 5-10 avril 1965, Davos, Suisse, p. 304-15. (Publication No. 69 de l'Association Internationale d'Hydrologie Scientifique.)

\section{MOVEMENT STUDIES ON A HANGING GLACIER IN RELATION WITH AN ICE AVALANGHE}

\author{
By ANDré FLotron \\ (Vermessungsbüro, Meiringen, Switzerland)
}

Abstract. In 1972 the state of a hanging glacier on the Weisshorn gave cause for alarm, as part of it seemed to be accelerating and a repetition of an earlier avalanche of ice seemed possible (see Röthlisberger, previous abstract). For this reason movement surveys were undertaken. The various surveying methods applied on the Weisshorn are outlined and the 
accuracy of the measurements is given. By least-square analysis different types of curves have been fitted to the data for velocity versus time. The best fit obtained so-far has been with hyperbolae. The confidence of extrapolations from such curves is discussed in relation to forecasts. By evaluating repeated photographs taken by an automatic camera from a single position, using a stereo plotter, the flow pattern has been established at the surface, part of the front, and one of the lateral faces of the ice mass. Changes with time caused by the deformation of the ice mass, the formation of crevasses and the crumbling away of the ice at the edge have been observed.

\title{
UTILIZATION OF DYNAMIG AND PHYSIGAL PROPERTIES OF IGE IN UNDERGROUND MINING OPERATIONS
}

\author{
By Henning Fangel \\ (Svedala-Arbrå A.B., Svedala, Sweden)
}

Abstract. In sub-level caving mining operations, the lateral walls cave in. This results in dilution of the mineral content of the produced ore by $15 \%-20 \%$ waste rock. Also $15 \%-$ $20 \%$ of the valuable ores are lost in the caved wall material that is left behind in the mined-out rooms. Placing ice, in the form of a small glacier, in the mine-room before the lateral walls start to cave, permit complete recovery of ore reserves without dilution. The glacier will advance at a rate permitted by ore extraction processes, in accordance with glaciological theories and laws.

Volumes of ice that are required may be calculated from ore extraction rates, power consumed in the mine, ventilating air volumes and temperatures, specific heat and thermal conductivity of the lateral rock. The required ice volumes can be produced through natural freezing of water, where the winter temperatures regularly fall below $0^{\circ} \mathrm{C}$ for a predictable period every winter. Use of ice as a mining aid reduces costs of the ore extraction process by about one-third and increases value of the produced ore by about $20 \%$. Thus, the value of a given orebody is increased by about $30 \%$ relative to the values experienced in the most efficient mines of today.

\section{DISCUSSION}

J. W. Glen: How safe are the procedures you are proposing? Is there a danger of ice falling on the men or machinery mining below? Is there a danger of running out of ice at the top with consequent rock-wall falls?

H. Fangel: The proposed procedures are as safe as tunnelling, and safer than any other known mining method. Men and equipment will never enter under uncontrolled roof nor have to load or secondarily blast caved rock, because they do not occur, according to the method. Men and machines will not have to work outside the cross cuts or drifts. Ice pressures against piles of blasted ore in the ore-extraction zone are high and ice is found in its plastic state. The whole process is based on and depends upon the ice having the potential of moving into the mine void faster than extraction rates plus melting losses.

A reservoir of ice ought to be produced in the pit (or day opening) in order to bridge mild winters or water shortages. In later stages of the life of an ore body when it is assured that the volumes of ice already inside the mine will last for the whole remaining life of the mine, further provisions of ice may be suspended. If the rock wall should cave in, this will in no way influence the operations deep inside the mine. Actually, closure of the mine and termination of operations may be prepared by dumping waste-rock, tailings, etc. on top of the ice, and then filling up the open-pit to prepare for reclamation of the mine site. 